Article

\title{
Agricultural Waste Recycling Optimization of Family Farms Based on Environmental Management Accounting in Rural China
}

\author{
Lulu Yang ${ }^{1,2, *}$ Xu Xiao $^{1}$ and $\mathrm{Ke} \mathrm{Gu}^{3}$ (D) \\ 1 Business School, Central South University, Changsha 410012, China; xiaoxucs@163.com \\ 2 Business School, Hunan Agricultural University, Changsha 410128, China \\ 3 School of Computer and Communication Engineering, Changsha University of Science and Technology, \\ Changsha 410114, China; gk4572@163.com \\ * Correspondence: yll525@hotmail.com; Tel.: +86-138-7492-2141
}

check for

updates

Citation: Yang, L.; Xiao, X.; Gu, K. Agricultural Waste Recycling Optimization of Family Farms Based on Environmental Management Accounting in Rural China. Sustainability 2021, 13, 5515. https:// doi.org/10.3390/su13105515

Academic Editors: Bazyli Czyżewski, Sebastian Stępień and

Łukasz Kryszak

Received: 11 April 2021

Accepted: 10 May 2021

Published: 14 May 2021

Publisher's Note: MDPI stays neutral with regard to jurisdictional claims in published maps and institutional affiliations.

Copyright: (c) 2021 by the authors. Licensee MDPI, Basel, Switzerland. This article is an open access article distributed under the terms and conditions of the Creative Commons Attribution (CC BY) license (https:/ / creativecommons.org/licenses/by/ $4.0 /)$.

\begin{abstract}
In the process of production and operation of family farms, a large amount of agricultural waste, such as livestock and poultry manure, has not been effectively treated in time, causing serious pollution to the environment. Moreover, livestock and poultry manure are the kind of resources that can be recycled to fertilize crops, which can benefit family farms both economically and environmentally. Adoption of manure biogas digesters by family farms can improve sustainability by not only decreasing input use and resource losses, but also reducing environmental pollution. Additionally, Material Flow Cost Accounting (MFCA) is considered to be the most representative environmental management accounting tool. MFCA can be expanded to account for and calculate environmental damages, so as to better reflect the economic and environmental sustainability of agricultural systems. According to the basic principles of material flow cost accounting and characteristics of family farms, we propose an agricultural-waste-recycling model for Chinese family farms that is based on the extended MFCA in this paper. We first investigate Chinese family farms in Hunan Province, and then optimize an agricultural-waste-recycling model by extended MFCA. Finally, based on our proposed model, we make a two-dimensional analysis on the internal resource cost and external environment damages for agricultural-waste recycling. Our analysis shows that visualization of monetization of resource losses can optimize manure recycling through better decision-making, which can increase the sustainability of family farms.
\end{abstract}

Keywords: agricultural-waste recycling; Material Flow Cost Accounting; family farm; sustainable development

\section{Introduction}

With the rapid development of modern agriculture, the shortage of agricultural resources is getting more serious. At the same time, increasing agricultural waste has contributed to pollution of rural environments. Resource constraints and environmental pollution have challenged the sustainable development of agriculture [1,2]. Sustainable development refers to "not only ensuring the sustainable development of economy today, but also not consuming the future resources and environment" [3]. There are some differences between sustainable development and traditional extensive development. Sustainable development emphasizes that development is based on the premise of not sacrificing ecosystem integrity. Agricultural sustainable development is facing new challenges. Both developed and developing countries attach great importance to the sustainable development of agriculture [4-8]. Agricultural sustainable development solves the three pillars of sustainable development by simultaneously assessing environmental, economic, and social issues related to agricultural practice [9-12], where economics is essential for sustainable development, since family farms need to be in business in order to benefit the environment and local communities. 
Family farms are the main contributors to agriculture and our food supply $[13,14]$. Low-input, high-yielding, and integrated agricultural systems can reduce pressure on agricultural resources and minimize environmental impacts [15]. According to the principle of sustainable development, family farms can optimize material recycling which can result in increased yields and profits, as well as reduced non-point source pollution [16,17]. Under the traditional production model, agricultural wastes such as livestock manure generated in the production process are directly discharged without any technical treatment. Adoption of biogas digesters can reduce such pollution by converting livestock wastes to marketable assets. Use of biogas digesters for livestock manure is part of a more general framework to recycle natural resources to improve sustainable development of the economy, society, and the natural environment [18].

Recent intensification of family farms around the world has caused significant environmental pollution $[19,20]$. The family farm has taken advantage of economics; however, it has also brought serious problems of environmental pollution [21]. Therefore, it is necessary to use waste recycling to reduce pollution and increase economic benefits [22]. In rural areas, agricultural waste pollution has exceeded the level of industrial pollution and has become the main source of non-point source pollution. In order to realize the sustainable development of family farms, agricultural wastes can be turned into valuable resources through recycling [23]. Previous studies on the recycling of agricultural waste have mainly focused on livestock manure and crop straw that contain a lot of organic matter [24]. After reasonable treatment and final reuse, agricultural wastes can produce certain economic value, reduce environmental pollution, and maintain high levels of agricultural development at the same time.

Researchers have improved processes used to recycle agricultural wastes, which include use of Rhizobia bacteria in addition to other processes. The recycling of phosphate fertilizer is discussed from the perspective of food security [25]. Agricultural-irrigationwastewater recycling treatment can also promote crop production [26]. Crop straw and livestock manure can be recycled through fermentation technology to produce biogas energy for clean production, and can also be transformed into high-quality agricultural organic fertilizer $[27,28]$. Biogas digesters have become more common on rural Chinese family farms. We present our visual representation of agricultural waste recycling, using Chinese pig-farm biogas digestion of hog manure as an example (Figure 1).

It is vital to understand different models used to represent the recycling of agricultural wastes [29-31]. For example, Life Cycle Assessment (LCA) is an important tool to support recycling decision-making. Application of Life Cycle Cost (LCC) has also developed rapidly. However, it is easy to confuse the concepts of related cost analysis tools, and the boundaries of various cost analysis systems are also not clear [32,33]. Therefore, we decided to use the Material Flow Cost Accounting (MFCA) method.

Material flow analysis is an effective method to evaluate the sustainability of social and economic development and reflect environmental changes [34-36]. Material Flow Cost Accounting (MFCA) is known as one of the most basic environmental-management accounting tools [37]. MFCA highlights the relationship between accounting elements and environment elements in order to make better management decisions [38]. MFCA was first applied in Germany to calculate related costs by building the material flow model, but the calculation process is more complex. In order to make MFCA more operational, Japanese scholars have further improved this method. In 2008, Japanese researchers jointly drafted an international standardization proposal on MFCA. During September 2011, the International Organization for Standardization technical committee (ISO/TC 207) issued the General Framework of Environmental Management-Material Flow Cost Accounting [39-41]. This manual covers the research framework of MFCA, which includes the determination of relevant general terms, objectives and principles, basic elements, and implementation steps [42]. The abovementioned standard has been recognized and promoted globally. The principle and method of MFCA has become an important basis for waste management and decision-making $[43,44]$. 


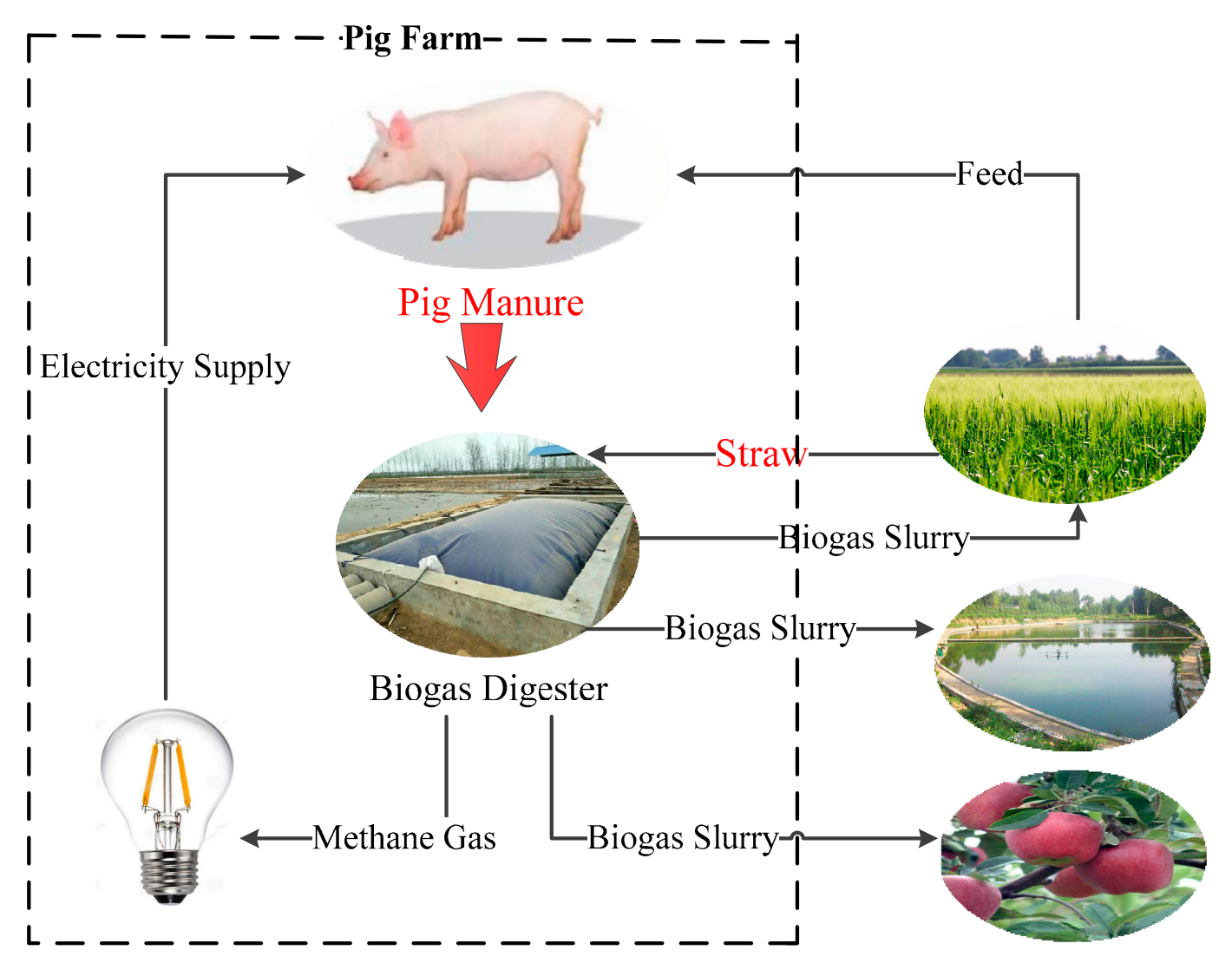

Figure 1. Framework of agricultural-waste recycling in pig farm.

Current studies of family-farm waste recycling have mainly focused on technical characteristics. Fewer studies have been conducted that integrate economic and environmental benefits based on sustainable development theory. MFCA is a type of environmental management accounting. It provides a way to analyze the resource losses more comprehensively on family farms. This paper aims to provide a reference for the development of agricultural waste recycling in general. Based on the principle of Material Flow Cost Accounting (MFCA), the objective of our research is to apply the MFCA model to evaluate biogas digesters on Chinese hog farms in order to quantify costs related to (a) resource losses and (b) environmental damages. We show that application of this MFCA model can indicate how Chinese family farms can be more sustainable for not only farmers but also government agencies assisting China's agricultural community.

\section{Methodology of Extended MFCA for Family Farms}

\subsection{Basic Principles of Material Flow Cost Accounting}

In the traditional cost accounting system, the standard cost method is among the most widely used. It divides the cost items involved in the family farm into direct materials, direct labor, other direct costs, and overhead, and it counts all production-related input costs into the value of finished products, including waste of materials and resources in the production process. During the actual production and operation process, the waste of materials and resources is inevitable, but if these wastes are recycled, wastes can produce value. Therefore, traditional accounting methods do not consider the recycling of resources, nor accurately reflect the value of wastes.

Material Flow Cost Accounting (MFCA) is a new research perspective of resource management, environmental protection, and economic benefits in order to promote the sustainable development of family farm. Therefore, the purpose of MFCA is to visualize the loss of resources. This type of cost accounting method explains the output of material flow in a certain link and the amount of wastes from two aspects: physical units and 
monetary value $[45,46]$. The basic view of material flow accounting is that the impact of human activities on the environment depends to a large extent on the quality and quantity of natural resources, as well as substances and waste discharged into the environment from economic systems. The use of natural resources will cause the exhaustion of resources, while the discharged substances and waste will cause environmental pollution. Accurately estimating the indirect environmental costs of not adequately recycling agricultural wastes can quantify the value of integrated farming systems. This can justify capital investment in systems like manure biogas digesters, which can increase farm profits by reducing purchased external inputs. These profits can then be re-invested to cover annual farm maintenance of these newly installed technologies.

However, the traditional MFCA method mainly focuses on the "monetization value of positive products", does not further calculate the "environmental damage cost", and fails to analyze and provide a direct monetized basis from an accounting perspective. Traditional MFCA has difficulty both measuring negative products accurately and estimating the impacts of farm wastes on the environment. Our study on Chinese family hog farms expands the MFCA accounting method and combines sustainable development of the family farm with environmental management accounting. Through the accurate calculation and indirect costs of not recycling hog manure, our models can help farm managers reduce nutrient losses through closed-loop nutrient and waste recycling.

\subsection{Material Type of Agricultural-Waste Recycling}

Material Flow Cost Accounting (MFCA) is based on material flow analysis between the natural environmental system and the farm-level socioeconomic system. MFCA can explore the relationships between specific inputs, outputs, and wastes during farm-level production. It provides an effective quantitative analysis tool for measuring the sustainable development of the economy and the utilization rate of resources. Therefore, applying the MFCA method requires understanding the types of materials involved.

The traditional Chinese family hog farm has concentrated resource use (e.g., feed, energy, etc.) when breeding of sows and rearing piglet litters. This stage of hog production can directly discharge pollutants and wastes into watersheds without centralized treatment of excreta. According to the theory of sustainable development, the goal of family farm is to maximize economic and environmental benefits. While pursuing economic benefits, family farms should make full use of the materials involved in the production process, so as to reduce the input of material resources, reduce the negative impact on the environment during the production process, and increase food production [47-50]. Therefore, it is important to identify the input and output types of materials involved. Taking the integrated hog-breeding farm as an example, the types of material involved in the production process are shown in Table 1.

Biogas digesters are constructed on Chinese family farms based on principles of material flow in ecological systems. Biogas, biogas slurry, and biogas residue can be obtained by composting, anaerobic fermentation, and other specialized treatment. Some of the treated manure contains nitrogen, phosphorus, potassium, and other elements, which can play a role in improving soil fertility. Biogas solids are suitable for use as fertilizer directly applied to crop fields. Some feces and sewage are fermented by biogas engineering to produce biogas, which is collected and utilized for power generation after purification. Biogas engineering is an important intermediate link in the agricultural-waste-recycling model, and it can be an important contributor to appropriate recycling of farm manure and wastes.

At the same time, the main waste straw produced in the process of grain cultivation is also a valuable renewable resource, which is an important component of biomass resources. In traditional agricultural systems in China, straw is the waste left after harvest. It is one of the most important fuels in rural areas. A large amount of straw is usually burned directly for heating, power generation, and other agricultural activities. This results in carbon dioxide emissions and a waste of carbon resources. Improved waste recycling 
involves using straw as a moisture-conserving mulch or for livestock feed and bedding. This can increase recycling efficiency by returning the carbon in straw back into integrated crop-livestock systems rather than being lost as greenhouse gas emissions.

Table 1. Material types for Chinese family hog farms.

\begin{tabular}{|c|c|c|c|c|c|c|}
\hline $\begin{array}{l}\text { Quantity } \\
\text { Center }\end{array}$ & Type & Name & Unit & Type & Name & Unit \\
\hline \multirow{6}{*}{$\begin{array}{l}\text { Livestock } \\
\text { production }\end{array}$} & \multirow{4}{*}{$\begin{array}{c}\text { Raw } \\
\text { material }\end{array}$} & $\begin{array}{l}\text { Breeding } \\
\text { livestock }\end{array}$ & $\mathrm{kg}$ & Product & $\begin{array}{l}\text { Commercial } \\
\text { livestock }\end{array}$ & $\mathrm{kg}$ \\
\hline & & Feed & $\mathrm{kg}$ & \multirow{2}{*}{ Waste } & $\begin{array}{l}\text { Livestock } \\
\text { manure }\end{array}$ & $\mathrm{kg}$ \\
\hline & & $\begin{array}{l}\text { Chemical } \\
\text { fertilizer }\end{array}$ & $\mathrm{kg}$ & & $\begin{array}{l}\text { Diseased } \\
\text { livestock }\end{array}$ & $\mathrm{kg}$ \\
\hline & & Pesticides & $\mathrm{kg}$ & & & \\
\hline & \multirow{2}{*}{ Energy } & Electricity & Kwh & & & \\
\hline & & Water & $\mathrm{m}^{3}$ & & & \\
\hline \multirow{5}{*}{ Grain field } & \multirow{3}{*}{$\begin{array}{c}\text { Raw } \\
\text { material }\end{array}$} & Seed & $\mathrm{kg}$ & Product & Grain & $\mathrm{kg}$ \\
\hline & & $\begin{array}{l}\text { Chemical } \\
\text { fertilizer }\end{array}$ & $\mathrm{kg}$ & Waste & Straw & $\mathrm{kg}$ \\
\hline & & Pesticides & $\mathrm{kg}$ & & & \\
\hline & \multirow{2}{*}{ Energy } & Water & $\mathrm{m}^{3}$ & & & \\
\hline & & Electricity & Kwh & & & \\
\hline \multirow{3}{*}{$\begin{array}{l}\text { Biogas } \\
\text { project }\end{array}$} & \multirow{2}{*}{$\begin{array}{c}\text { Raw } \\
\text { material }\end{array}$} & $\begin{array}{l}\text { livestock } \\
\text { manure }\end{array}$ & $\mathrm{kg}$ & \multirow{3}{*}{ Product } & Biogas & $\mathrm{m}^{3}$ \\
\hline & & Straw & $\mathrm{kg}$ & & $\begin{array}{l}\text { Biogas } \\
\text { slurry }\end{array}$ & $\mathrm{kg}$ \\
\hline & Energy & Electricity & Kwh & & $\begin{array}{l}\text { Biogas } \\
\text { residue }\end{array}$ & $\mathrm{kg}$ \\
\hline
\end{tabular}

\subsection{Steps of Extended Material Flow Cost Accounting for Family Farms}

Material Flow Cost Accounting (MFCA) is based on the principle of material balance, that is, the inflow and outflow materials are equal (Equation (1)). The purpose of MFCA is to visualize the loss of resources. Extended MFCA is divided into five steps.

$$
\sum \text { Input Product }=\sum \text { Output Product }
$$

The first step is to identify cost items. Different from the standard cost accounting method, the MFCA system divides cost items into three categories, namely material cost, system cost, and energy cost which cannot be directly included in a single quantity center. All three types of cost need to be allocated. The reclassification of cost items will clearly reflect the material waste, labor costs, and energy losses concealed under the traditional cost accounting method. Components of each cost center is shown in Table 2.

Table 2. Cost center classification components.

\begin{tabular}{cc}
\hline Cost Items & Object of Study \\
\hline Material cost (MC) & Major, secondary, and auxiliary production materials \\
\hline System cost (SC) & Labor cost, equipment depreciation, etc. \\
\hline Energy cost (EC) & Electricity and fuel costs. \\
\hline
\end{tabular}


The second step is to distinguish the positive and negative products of each quantity center, and calculate the proportion of positive and negative products. This step is the basis of MFCA application. Referring to the concept of "unit" in activity-based costing, the set of accounting objects is regarded as a "quantity center" to calculate the input and output of resources. According to the environmental management standard system, the output materials are divided into two categories: positive products and negative products. The final product or the semi-finished product flowing to the next process is called "positive product". The "negative product" includes some unqualified products and by-products, materials, waste products of daily consumption, etc. Some of these can be recycled directly, others need special treatment through technical methods, and then put through the production process again. An example of a quantity center is shown in Figure 2.

$$
\sum \text { Output Product }=\sum \text { Positive Product }+\sum \text { Negative Product }
$$

Therefore, according to the principle of material balance, if the quantity of input material is equal to that of output material in the system, the quantity of input material and output positive products can be calculated first. These quantities can be accurately measured, while the quantity of negative products are difficult to measure. Negative products can be obtained by deducting positive products from input materials, so as to calculate the positive products and negative products of each quantity center for better resource loss visualization.

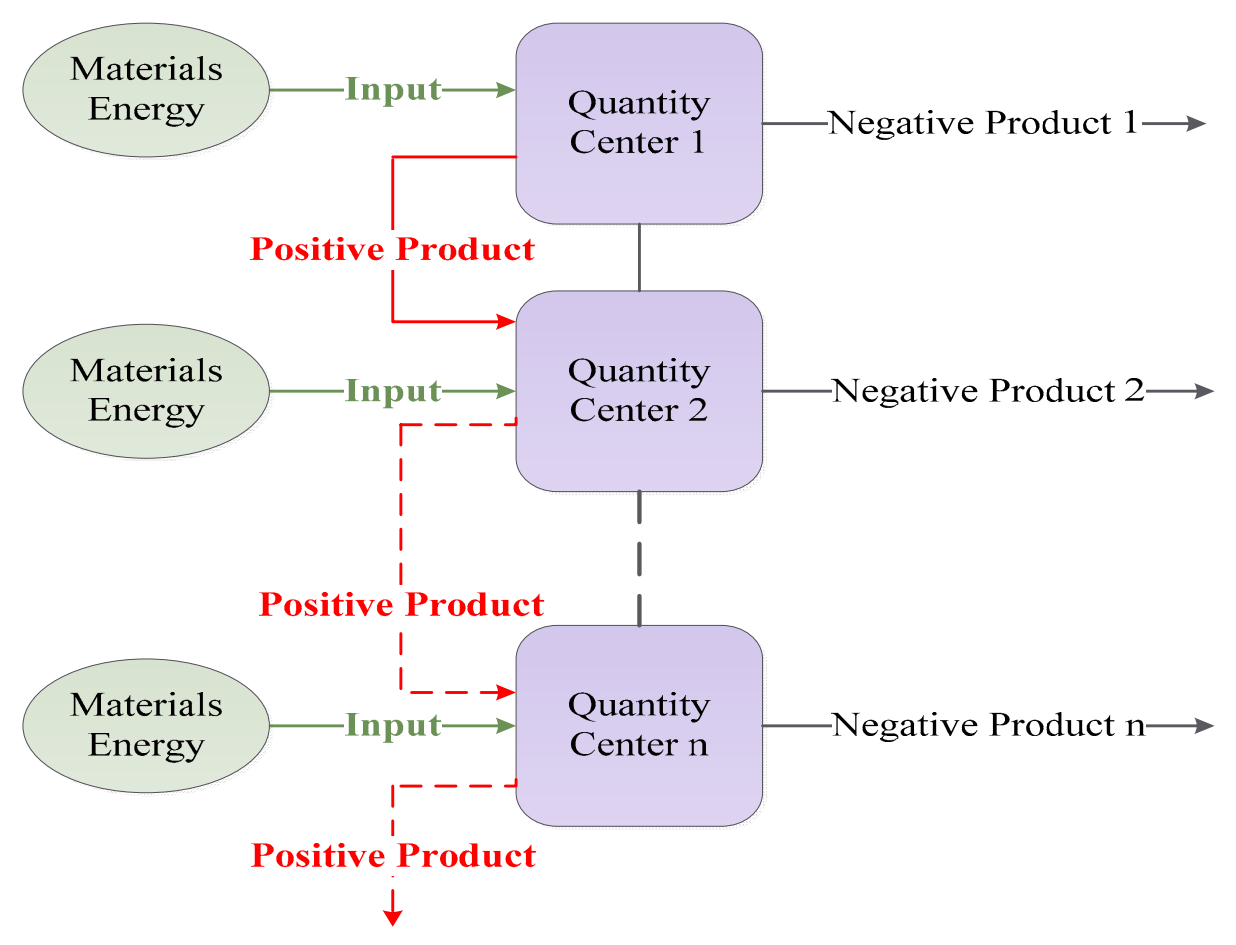

Figure 2. Example of quantity center of Material Flow Cost Accounting.

The third step is to prepare the cost flowchart based on material flow analysis shown in Figure 3. According to the material flow of each quantity center, the input and output quantity of material is transformed into cost representation. At the output end of the quantity center, the total cost is allocated according to a certain standard, and the cost accounting flowchart based on material flow analysis is prepared. As shown in Figure 3, which represents material cost (MC), system cost (SC), and energy cost (EC). On the basis of quantitative accounting, the cost of new input and the cost transferred from the center of material flow are allocated. This step is the core of Material Flow Cost Accounting. 


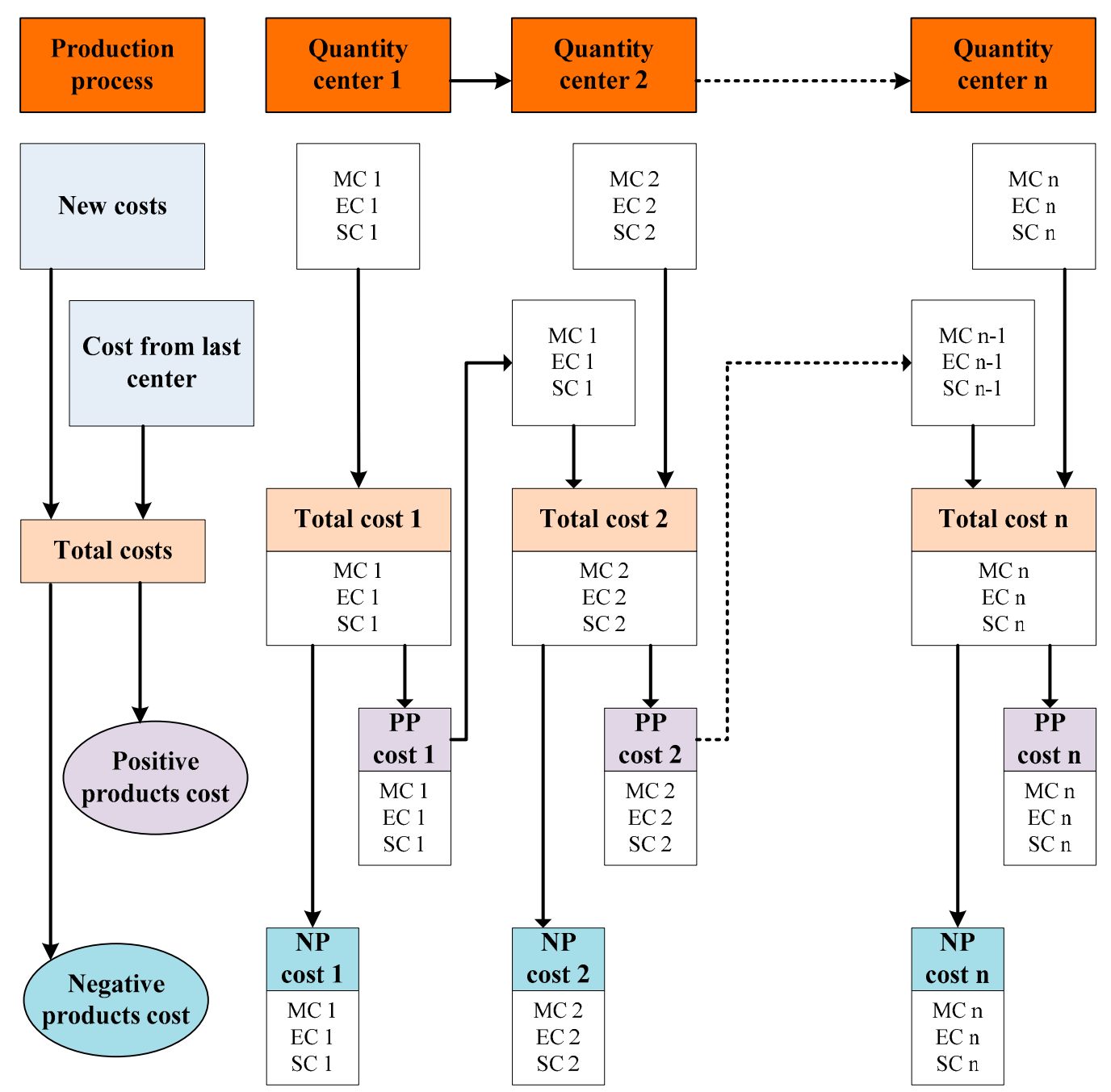

Figure 3. Cost flowchart for Material Flow Cost Accounting.

The fourth step is to prepare the material flow cost table (Table 3). Within the boundary of Material Flow Cost Accounting, according to the principle of cost allocation, the cost of each quantity center is allocated between the positive and negative products of its output. The costs of positive and negative products can also be calculated for each quantity center. Collecting and distributing the cost of products makes the resource loss cost and composition of negative products appear. On this basis, the total costs of positive products $\left(\mathrm{TC}_{\mathrm{pp}}\right)$ and negative products $\left(\mathrm{TC}_{\mathrm{np}}\right)$ in the whole production process are calculated. Compared with the total input costs, the positive-product rate and negative-product rate of each center are calculated, and the material-flow-cost table is compiled. By comparing and analyzing these two rates, we can judge the economic cost-effectiveness of the whole production process, as well as the cost composition of products and wastes. We also can find out the key points of resource loss and identify the production links that need to be strengthened, improve the efficiency of resource utilization, and fully realize the dual significance of reducing waste generation to improve efficiency and reducing environmental load. Using extended MFCA, the family farm may be able to achieve sustainable development goals.

The fifth step is environmental damage cost (EDC) accounting. The confirmation of environmental damage cost is the key to extended MFCA. It is difficult to monetize environmental damages. In the traditional MFCA system, the impact of waste discharge on the environment is not considered from the perspective of monetary value. In fact, in the process of continuous consumption of resources and waste generation, waste discharge has caused pollution and damage to the natural ecological environment, resulting in external 
environmental damage costs. Agricultural production and the natural environment are inseparable, so the cost of environmental damage has a huge impact on the total value of the final product of the whole agricultural production system. For example, the family farm using biogas digester will reduce the economic cost and environmental cost.

Table 3. Material flow cost table equations for positive and negative products.

\begin{tabular}{ccccc}
\hline & Material Cost & System Cost & Energy Cost & Total \\
\hline Positive Product & $\sum_{i=1}^{n} M C_{p p n}$ & $\sum_{i=1}^{n} S C_{p p n}$ & $\sum_{i=1}^{n} E C_{p p n}$ & $T C_{p p}$ \\
\hline Positive-Product Rate & $R_{M C p p}$ & $R_{S C p p}$ & $R_{E C p p}$ & $R_{p p}$ \\
\hline Negative Product & $\sum_{i=1}^{n} M C_{n p n}$ & $\sum_{i=1}^{n} S C_{n p n}$ & $\sum_{i=1}^{n} E C_{n p n}$ & $T C_{n p}$ \\
\hline Negative-Product Rate & $R_{M C n p}$ & $R_{S C n p}$ & $R_{E C n p}$ & $R_{n p}$ \\
\hline
\end{tabular}

MFCA is considered extended since, on the one hand, it breaks through the limitation of ignoring the value of agricultural waste under the traditional accounting method by making transparent both resource use and the monetary value of waste. On the other hand, according to the principle of material flow balance, extended MFCA internalizes environmental costs of waste discharge into the cost accounting system. Clear valuation of environmental damages can better inform farm managers to make better decisions, such as when to adopt biogas digesters.

\section{Case-Study Analysis Results}

\subsection{Case-Study Flowchart}

Compared to traditional pig farms, modern pig farms adopt phased scientific breeding management. In the preparation process, pig farms purchase related equipment, feed, veterinary drugs, and other production materials. In the breeding-livestock production process, piglets are considered to be a positive product that is fattened during confinement to produce marketable hogs. At the same time, porcine fecal and gaseous wastes are produced. Biogas digestion on pig farms can be divided into four quantity centers, with each center utilizing inputs to produce outputs (Figure 4).

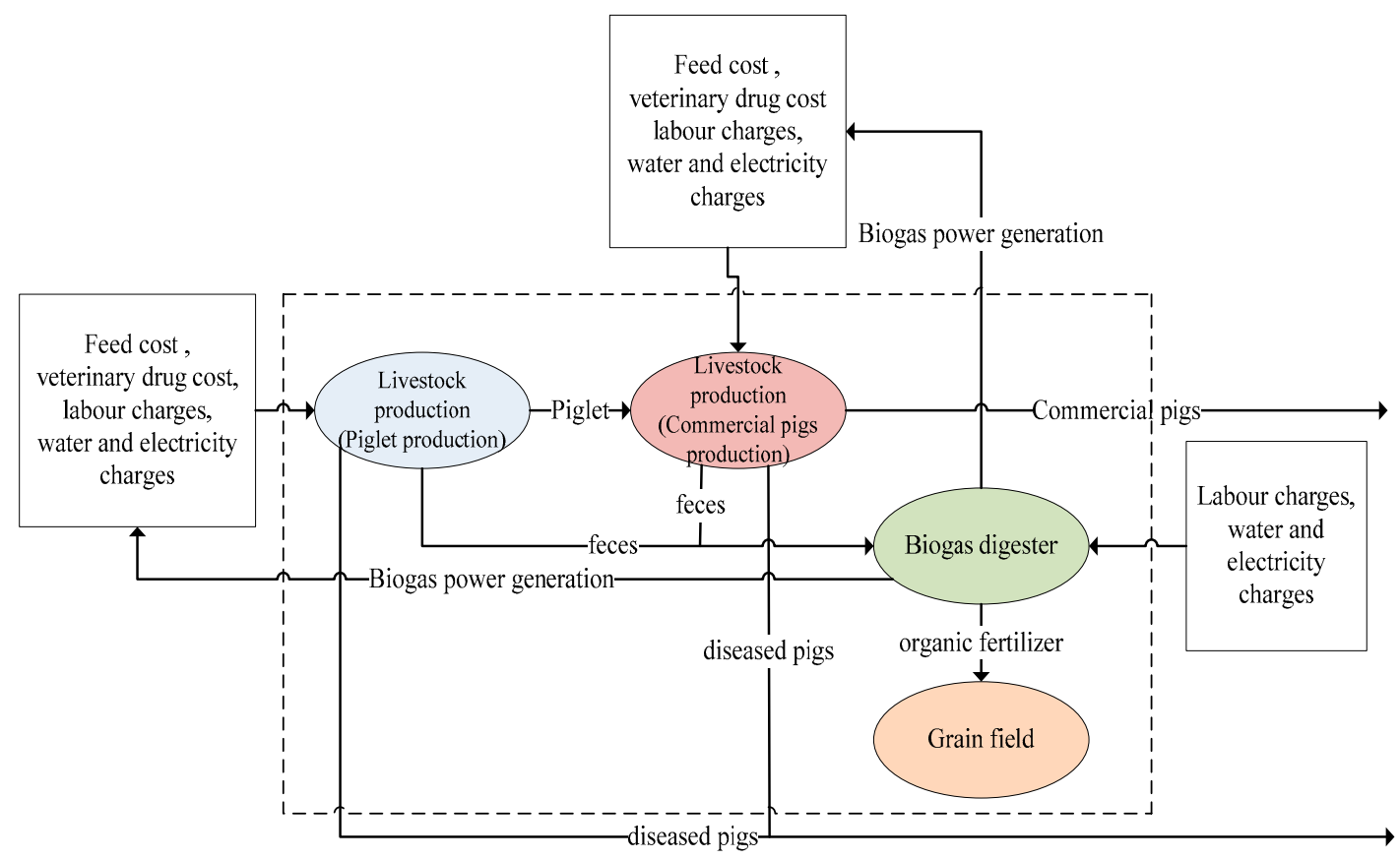

Figure 4. Chart of production flow of pig farm. 


\subsection{Case-Study Farm Production and Cost Accounting}

\subsubsection{Pork and Biogas Production}

The sample selection of this paper is based on the field investigation with reference to the relevant production data and financial data from financial reports (2016), Hunan Province statistics and Ministry of Environmental Protection of China (MEP). This pig farm was founded in 2009, located in Dong Kou County, Shao Yang City, Hunan province, China, covering an area of $234.8 \mathrm{mu}$. The pig farm has 3912 live pigs annually, including 378 sows. In order to purify the environment and reduce pollution and production cost, the construction of a biogas digester for energy savings and emissions reduction was completed in 2016.

Our case-study hog farm was consistent with other pig farms in Hunan Province, requiring $1533 \mathrm{~kg}$ of feed per sow per year. The unit price of feed is $¥ 1.45 / \mathrm{kg}$. One sow produces 19.8 piglets and 18.7 fattening piglets on average, with a survival rate of $94.4 \%$. Piglets weigh $19-20 \mathrm{~kg}$ in 60 days and requiring $55-60 \mathrm{~kg}$ feed. The market price of feed is $¥ 2.1 / \mathrm{kg}$ (US\$0.32/ kg, JP¥32.76/ kg). Fattening pigs generally need $120-180$ days to grow up to $110-120 \mathrm{~kg}$ for sale, require $335-340 \mathrm{~kg}$ feed. The market price of fertilizer is $¥ 1.50 / \mathrm{kg}$ (US $\$ 0.23 / \mathrm{kg}$, JP¥23/ kg). Assuming that the fattening pigs are commercial pigs weighing $120 \mathrm{~kg}$, fecal waste and urine generated annually averages 230 and $167 \mathrm{~kg}$, respectively. Production costs of pig breeding are the most for feed $(74 \%)$, followed by purchased piglets (20\%); animal protection (4\%); and water and electricity use, shed loss, etc. ( $2 \%)$.

The development of modern pig breeding industry is inseparable from the construction of supporting facilities biogas digester. Biogas can replace coal, petroleum, liquefied gas, electric power, and other energy consumed by traditional pig farms. The biogas residue and biogas slurry produced by biogas digester can also be used as feed, bait, and other raw materials for agricultural enterprises. According to technical recommendations for Chinese hog production under normal management practices, it is necessary to build about 20 cubic meters of biogas digester to treat the livestock manure produced by 100 pigs at a cost of about $¥ 4000$. Since fermentation temperature, different regions and gas productions are different, the size of biogas digester is generally changed from 0.2 to 0.8 cubic meters, according to the different technology. Thus, a biogas digester can produce 20 to 80 cubic meters of gas per day. Biogas can replace the electricity and heat energy needed in daily life and work, and reduce the production and operation costs for farmers. Assuming that all the biogas produced can be converted into electrical power, 100 cubic meters of biogas can generate 195 to 243 kilowatt hours.

\subsubsection{Internal Cost Accounting}

According to the principle of Material Flow Cost Accounting and material-flow balance, the relevant data mainly include input raw materials, basic materials, output products, waste, and related emissions. In our scheme, the feed and drinking water consumed in the production process is considered into the material cost in quantity center; the cost of hydro power is included into the energy cost; the costs of labor, overhead and depreciation are included into the system cost.

In quantity center 1 , the material costs include the cost of sows feed, the cost of piglets feed and the cost of drinking water, which are totaled to $¥ 1,981,122$. The costs of water and electric power are included into the energy cost, which are allocated between the quantity center 1 and center 2, according to the pig weight. Further, since the drinking water of livestock and poultry in farms is often obtained from groundwater, the production cost is basically not generated for the use of water resources; then, the energy cost in the production stage mainly refers to $¥ 9120$ of electricity cost. Additionally, the labor cost $(¥ 21,621)$, manufacturing cost $(¥ 53,105)$ and depreciation cost $(¥ 445,521)$ are included into the system cost. These costs are also apportioned between the quantity center 1 and center 2 according to the pig weight. The survival rate of piglets in quantity center 1 is calculated to be $90 \%$, that is, the cost of treating diseased and dead pigs is about $10 \%$ of the whole cost of piglets. The produced feces pollution is $328,709 \mathrm{~kg}$. 
In quantity center 2, the weight of piglets transferred from quantity center 1 to quantity center 2 is $149,688 \mathrm{~kg}$. According to the material cost of $¥ 10$ per kilogram, the total material cost of fattening production stage is $¥ 8,858,219$. Similarly, the costs of water and electricity are included into the energy cost, totaling $¥ 20,436$. The system costs include veterinary drug cost, labor cost, piggery repair cost, related equipment purchase and installation cost, depreciation cost. In quantity center 2 , the labor cost is $¥ 340,538$, the manufacturing cost is $¥ 836,412$, and the depreciation of fixed assets is $¥ 537,363$, so the total system cost is $¥ 1,714,313$. Further, $848,232 \mathrm{~kg}$ pigs are sold and 3,418,572 $\mathrm{kg}$ feces are produced, where the survival rate of pigs is calculated to be $90 \%$ in quantity center 2 . So the cost of sick and dead pigs is apportioned as $10 \%$ of the cost of commercial pigs.

In quantity center 3 , the material cost mainly comes from the cost of treating livestock manure in quantity centers 1 and 2, and the cost of treating crop straw in quantity center 4. In this center, the allocated costs are $¥ 7,946,217$, where the material cost generated by the new auxiliary materials is $¥ 23,400$, and the system cost generated by mechanical maintenance, labor and equipment depreciation is $¥ 203,319$. Moreover, the output of biogas is 7300 cubic meters, which is partially used for power generation. Further, the biogas digester outputs 1367 tons of biogas slurry fertilizer and 37.5 tons of primary organic compost. Additionally, the power consumption is included in the energy cost. However, because part of the generated biogas can be used internally for power generation, there is no additional cost. Moreover, 400 tons of biogas slurry and 25 tons of primary organic compost can be sold every month. Therefore, it can be assumed that the biogas digester does not produce waste since transferred livestock manure and crop straw are fully utilized.

In quantity center 4, we assume that the land cost is not taken into account. Moreover, the biogas slurry and biogas residue from quantity center 3 can produce organic fertilizer which can be used for the grain field. Since the straw coefficient is set to 0.5 , costs are equally allocated for straw and grain respectively. Further, certain organic fertilizer can be obtained through the biogas system, and organic fertilizer can replace chemical fertilizer to be used for grain field. Therefore, the amount of chemical fertilizer used for grain field is reduced, which is in line with the reduction principle of the circular economy.

Based on the above analysis of the production process for a pig farm, Material Flow Cost Accounting can be used to determine the cost flow of waste recycling. The total material cost, energy cost, and system cost of positive and negative products are calculated (Figure 5). The currency data is also available in a Supplementary Material file as Figures S1 and S2 for US\$ and Japanese yen respectively.

\subsubsection{External Environmental Damage Cost Accounting}

The main difference between the extended MFCA and the traditional cost accounting method is the calculation of external environmental damage cost [51]. Wastes generated during the livestock production process include manure, dead animals, and greenhouse gases which can have a huge impact on the environment. Therefore, environmental costs need to be included in agricultural-waste-recycling models.

This paper introduces the life-cycle impact assessment method based on endpoint modeling (LIME), which has been popularized in Japan to measure the external environmental damage of agricultural waste from the perspective of monetization. External environmental damage costs were estimated (Table 4). Methane gas is emitted from livestock manure and is the main component of biogas. If a large amount of methane and carbon dioxide are directly emitted into the air, it can cause greenhouse warming. Chemical Oxygen Demand (COD) is another important indicator reflecting the organic pollution of water, which can represent the degree of water pollution. Nitrogen oxides produced by decaying organisms can form acid rain, reduce soil quality and harm crops. The total cost of external environmental damage is estimated at $¥ 118,193$. 


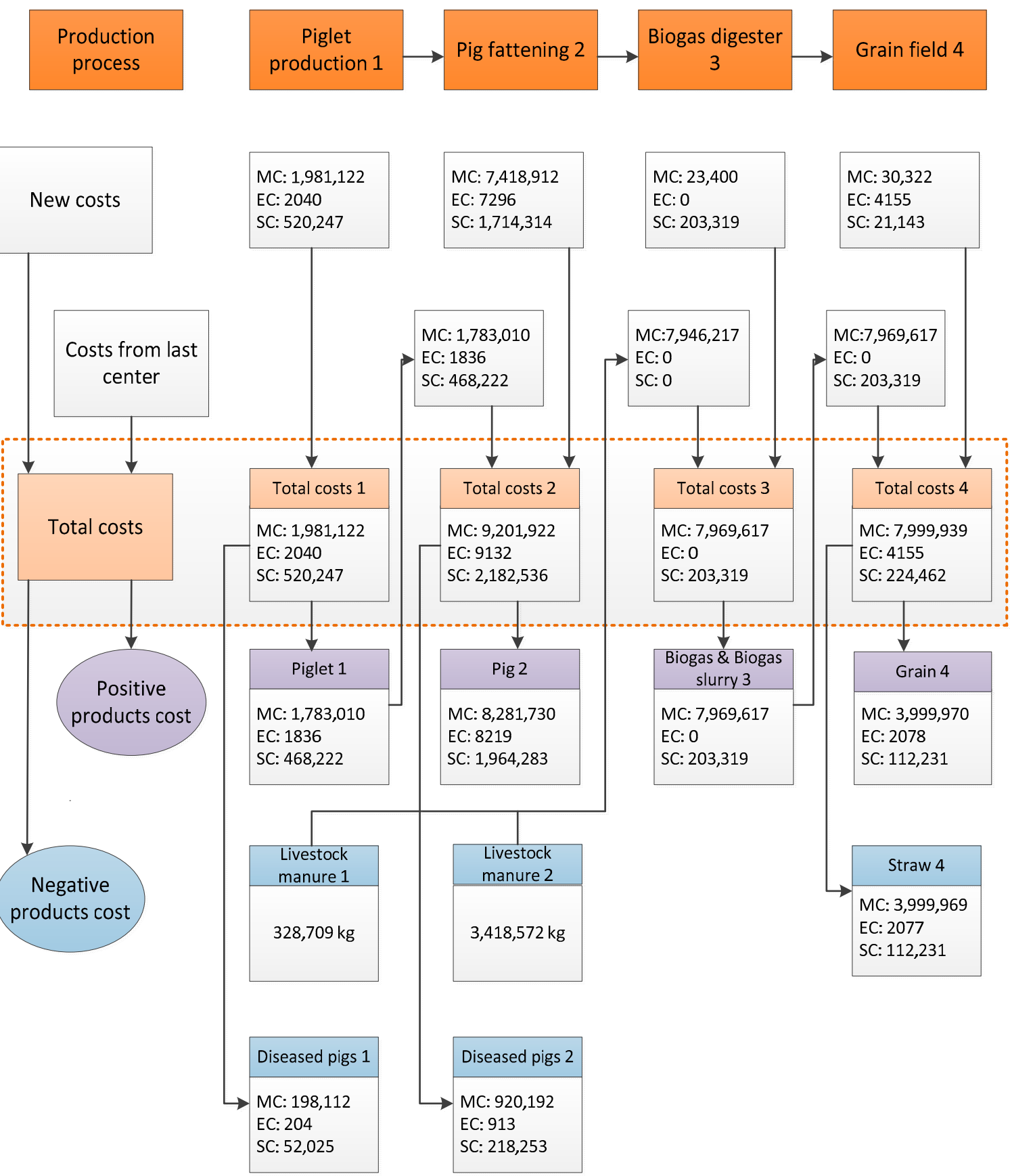

Figure 5. Cost flow based on material flow analysis (currency unit: Chinese $¥$ ).

Table 4. External-environmental-damage-cost accounting.

\begin{tabular}{cccccc}
\hline Type & $\begin{array}{c}\text { Quantity } \\
\text { (kg/Year) }\end{array}$ & $\begin{array}{c}\text { LIME } \\
\text { (Japanese } \\
\text { yen/kg) }\end{array}$ & $\begin{array}{c}\text { External } \\
\text { Environmental } \\
\text { Damage Cost } \\
\text { (Japanese yen) }\end{array}$ & $\begin{array}{c}\text { External } \\
\text { Environmental } \\
\text { Damage Cost } \\
\text { (Chinese yuan } ¥)\end{array}$ & $\begin{array}{c}\text { External } \\
\text { Environmental } \\
\text { Damage Cost } \\
\text { (US \$) }\end{array}$ \\
\hline $\mathrm{CO}_{2}$ & 967,910 & 1.74 & $1,684,163$ & 107,786 & 16,168 \\
\hline $\mathrm{CH} H_{4}$ & 273 & 4.43 & 1209 & 77 & 12 \\
\hline $\mathrm{COD}$ & 125,300 & 0.64 & 80,192 & 5132 & 770 \\
\hline $\mathrm{NO}_{x}$ & 576 & 141 & 81,216 & 5198 & 780 \\
\hline Total & & & $1,846,781$ & 118,193 & 17,730 \\
\hline
\end{tabular}




\subsection{Results}

Based on the above calculation results, we can clearly disclose the cost flow of agricultural waste recycling on our case-study pig farm. On the one hand, the cost of negative products accounts for $7 \%$ of the total cost. The material cost accounts for the largest proportion of the total cost. Negative products mainly consist of dead pigs. Livestock manure and straw can be recycled through biogas engineering. Assuming that no negative products were produced during biogas production, livestock manure and straw can be fully utilized. Under traditional cost accounting, the cost of material consumed by dead pigs is included in the cost of commodity pigs. According to the principle of Material Flow Cost Accounting, we can calculate the cost of dead pigs as negative products. Therefore, farmers can see the resource losses more intuitively. On the other hand, most of the material cost of the biogas digester comes from the feces pollution produced by quantity center 1 and center 2 .

As shown in Figure 6, there are seven axes from the center of the diagram grouped into three axes representing system production costs $(\mathrm{MC}, \mathrm{SC}$, and $\mathrm{EC})$ and four axes representing environmental costs of wastes generated $\left(\mathrm{CO}_{2}, \mathrm{CH}_{4}, \mathrm{COD}\right.$, and $\left.\mathrm{NO}_{\mathrm{x}}\right)$. The center of the figure shows the boundary of a family farm with a biogas digester. Outside of the boundary represents traditional family farms that do not use biogas digesters. Numbers represent relative costs point to point. Compared with the traditional family farm, the economic costs (red lines and rectangles) and environmental costs (blue lines and rectangles) are relatively lower by using the biogas digester. Moreover, the utilization ratio of resource is greatly improved. If the manure is used improperly in the biogas project, it will also cause the loss of resources.

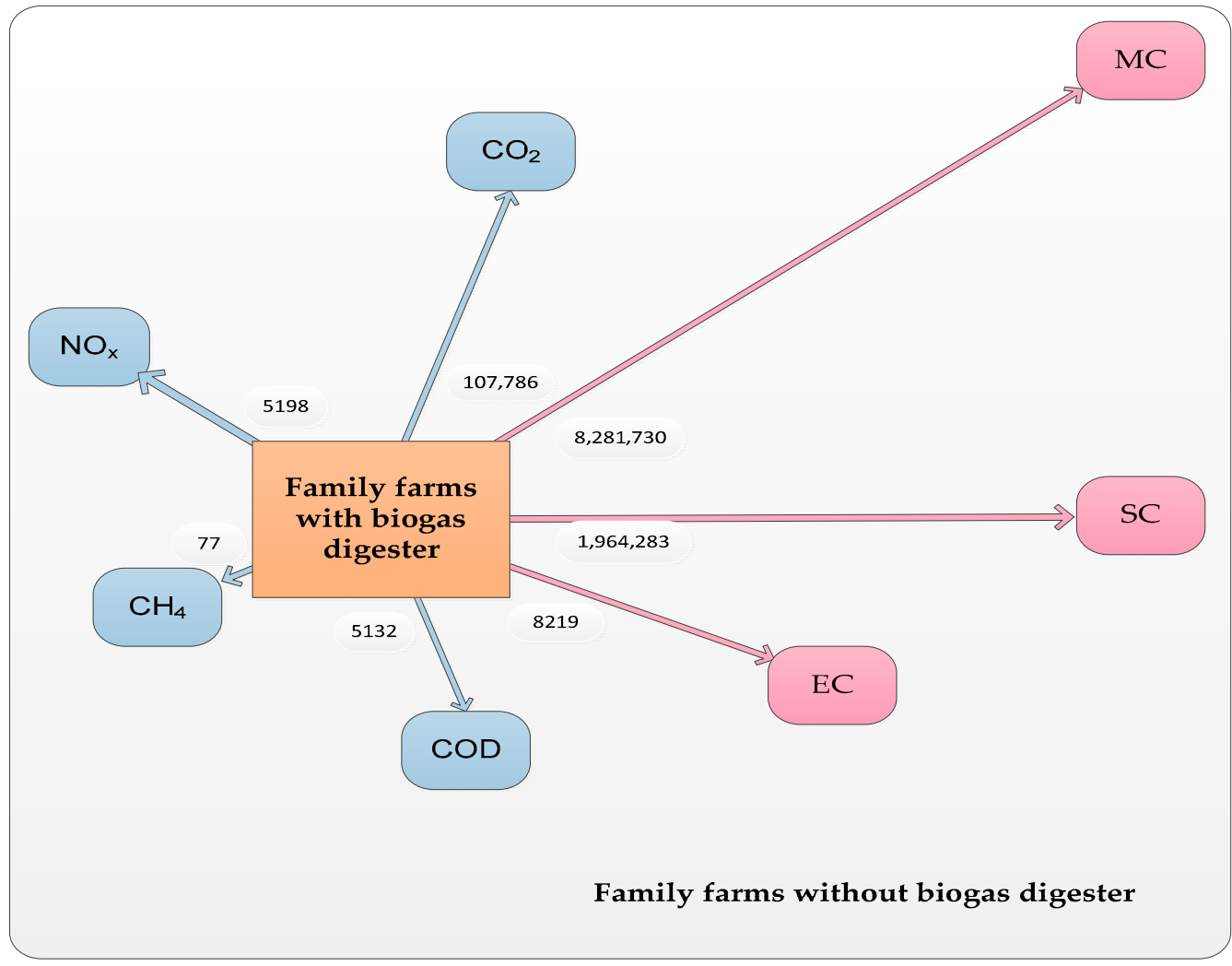

Figure 6. Costs of family farms with biogas digester (currency unit: Chinese $¥$ ).

Using the extended MFCA method, we estimated both internal resource costs and environmental costs of Chinese pig production with and without using a biogas digester. When biogas digesters are not used, agricultural livestock production wastes such as pig manure and straw were not effectively utilized and their values not captured. Moreover, the direct external discharge of wastes such as hog manure increases external environmental costs. 
When Chinese family farms producing pigs adopt biogas digesters, both production costs and external environmental costs are decreased. Thus, from an economic accounting perspective, biogas digesters can be a "win-win", conferring both economic and environmental benefits to farms willing and able to invest in such technologies.

\section{Discussion}

Increasing domestic demand for pork in China has accelerated hog production on family farms [52]. From a global nutrient-cycling perspective, Chinese hog farms are increasingly becoming nutrient sinks as purchased feed becomes concentrated as manure wastes on-farm resulting in eutrophication of watersheds and contributing to national greenhouse gas emissions [19]. Biogas digesters are becoming an increasingly popular technology used by livestock producers globally to better use nutrient and gaseous wastes from livestock manure [23]. Our results suggest that biogas digesters can simultaneously reduce both production costs and environmental costs of hogs produced on family farms in China. This improves on the prior literature but also highlights challenges that need to be addressed in the future.

We have provided a framework to compare economic material flows for livestock systems before and after implementation of agricultural-waste recycling. Past research on these systems used on family farms have focused exclusively on technological attributes without accounting for economic and environmental characteristics [25,26]. Limited research has been conducted on the integration of economic and environmental benefits based on sustainable development theory. According to the principle of Material Flow Cost Accounting, we attempted to optimize the agricultural-wastes-recycling model and identify the hidden costs, so as to determine the resources loss cost and environmental damage cost to improve the operation of family farms producing pigs in China.

Extended Material Flow Cost Accounting provided a way to analyze the resource losses comprehensively on family farms. Our case-study results show that the loss of agricultural resources in the process of recycling and the impact on the environment can be monetized and visualized by applying the cost-flow model. Furthermore, agriculturalwaste recycling has also a positive impact on local communities in rural China. It can reduce environmental pollution and provide employment opportunities from start-up businesses in China's rapidly emerging livestock-waste-treatment industry. However due to the uncertainty of agricultural-waste collection and accounting, it is difficult and complex to obtain accurate data, and the specific cost flow cannot be reflected in a short time. Therefore, the accuracy of our proposed method and model depends on whether farms can further improve the cost-accounting system, especially the accounting of waste.

The adoption of biogas digesters on livestock farms can be a key tool used to recycle agricultural wastes on farms. Livestock manure goes to waste since it is not valued as a stable composted fertilizer, electrical energy source, or potential heat co-generated for other integrated agricultural enterprises. Our results are consistent with studies that have shown that biogas digesters can reduce energy and fertilizer costs and produce environmental benefits $[53,54]$. By better quantifying the economic and environmental benefits of using a biogas digester for Chinese hog farmers, more local producers may be encouraged to adopt these systems. Assuming that total revenues are constant, projected reductions in annual costs should increase farm profits. Producers can then determine if such projected increases in annual profit can pay for the initial capital investment in biogas digesters and if so on what time horizon. Adoption of more biogas digesters by Chinese livestock producers can increase, as these farmers attach more value to the ability to produce stable composted fertilizer, electricity, and co-generated heat that can be used for other integrated agricultural enterprises [55-58].

Additionally, we have the following suggestions to optimize the current agriculturalwaste recycling of family farms and achieve the dual purpose of saving costs and reducing environmental pollution. Agricultural-waste recycling needs to establish standardized management. An important reason for the failure of waste recycling is the lack of corresponding 
standards and standardized management. Therefore, the expected effect of waste recycling cannot be achieved. Waste-recycling standardization is the product of waste-recycling development to a certain stage. The formulation of standardization provides important technical support for accelerating economies of scale in agricultural-recycling industries. The government should strongly support family farms that use biogas digesters to deal with livestock-manure pollution and give certain special subsidies or financial assistance.

\section{Conclusions}

In this paper, we aimed to optimize an agricultural-waste-recycling model in rural China. Here, the purpose of such optimization is to effectively reduce both input use and environmental pollution from hog manure. To better quantify the environmental impacts of hog farming on Chinese family farms, we used extended MFCA to account for and estimate environmental damages. Based on the extended MFCA method, we can conclude that, when the family farm adopts a biogas digester, both internal resource losses and externalized environmental damages are reduced. From an accounting perspective, we have demonstrated that adoption of biogas digesters can confer both economic and environmental benefits. Our results suggest that the extended MFCA method can be used as a viable alternative to other models measuring agricultural sustainability, as well as a complement to standard agricultural economic methods, such as production budgets and econometrics. However, since there are many different types of livestock farms in China, each with different production characteristics and types of wastes, the extended MFCA model needs to be adapted to each livestock industry. Future research should focus not only on the diversity of livestock industry wastes but also on how these wastes can be better integrated into other related industries. Expanding use of MFCA can be part of a process to increase the breadth and depth of optimizing livestock waste in China, as well as the rest of the world.

Supplementary Materials: The following are available online at www.mdpi.com/xxx/s1. Figure S1: Cost flow based on material flow analysis (US\$). Figure S2: Cost flow based on material flow analysis (JP¥).

Author Contributions: Conceptualization, L.Y. and X.X.; methodology, L.Y. and X.X.; validation, L.Y., X.X., and K.G.; formal analysis, L.Y. and X.X.; investigation, L.Y. and K.G.; resources, L.Y.; data curation, L.Y. and K.G.; writing-original draft preparation, L.Y. and K.G.; writing-review and editing, L.Y. and K.G.; visualization, L.Y. and K.G.; supervision, L.Y.; project administration, L.Y.; funding acquisition, L.Y. All authors have read and agreed to the published version of the manuscript.

Funding: This research was funded by the Project of Social Science Fund of Hunan Province in China, grant number 19YBA194. The APC was funded by the Project of Social Science Fund of Hunan Province.

Institutional Review Board Statement: Not applicable.

Informed Consent Statement: Not applicable.

Data Availability Statement: Restrictions apply to the availability of these data. Data was obtained from pig farm and are available from the authors with the permission of pig farm.

Acknowledgments: The authors gratefully acknowledge the support provided by the Project of Social Science Fund of Hunan Province (19YBA194) in China. The authors also would like to thank Central South University (China), Hunan Agricultural University (China) and Yating Wang for research grants.

Conflicts of Interest: The authors declare no conflict of interest. 


\section{References}

1. Su, Y.; He, S.; Wang, K.; Shahtahmassebi, A.R.; Zhang, L.; Zhang, J.; Zhang, M.; Gan, M. Quantifying the sustainability of three types of agricultural production in China: An emergy analysis with the integration of environmental pollution. J. Clean. Prod. 2020, 252, 1-14. [CrossRef]

2. Therond, O.; Duru, M.; Roger-Estrade, J.; Richard, G. A new analytical framework of farming system and agriculture model diversities: A review. Agron. Sustain. Dev. 2017, 37, 21. [CrossRef]

3. Savickiené, J.; Miceikiené, A. Sustainable economic development assessment model for family farms. Agric. Econ. Czech. 2018, 64, 527-535. [CrossRef]

4. Janvry, A.D.; Sadoulet, E. Agriculture for development in sub-Saharan Africa: An update. Afr. J. Agric. Resour. Econ. 2010, 5, 194-204.

5. Martín-Retortillo, M.; Pinilla, V. Patterns and causes of growth of European agricultural production, 1950 to 2005. Agric. Hist. Rev. 2015, 63, 132-159.

6. Goswami, R.; Saha, S.; Dasgupta, P. Sustainability assessment of smallholder farms in developing countries. Agroecol. Sustain. Food Syst. 2017, 41, 546-569. [CrossRef]

7. Volkov, A.; Morkunas, M.; Balezentis, T.; Sapolaite, V. Economic and Environmental Performance of the Agricultural Sectors of the Selected EU Countries. Sustainability 2020, 12, 1210. [CrossRef]

8. Mohamed, E.S.; Gouda, M.S. Assessment of Agricultural Sustainability in Some Areas West of Nile Delta. Egypt. J. Soil Sci. 2018, 58, 309-323. [CrossRef]

9. Goodland, R. Sustainable ecological agriculture in China. Ecol. Econ. 2013, 89, 203. [CrossRef]

10. Patrizi, N.; Niccolucci, V.; Castellini, C.; Pulselli, F.M.; Bastianoni, S. Sustainability of agro-livestock integration: Implications and results of Emergy evaluation. Sci. Total Environ. 2018, 622-623, 1543-1552. [CrossRef] [PubMed]

11. Janker, J.; Mann, S.; Rist, S. Social sustainability in agriculture-A system-based framework. J. Rural Stud. 2019, 65, 32-42. [CrossRef]

12. Sharifzadeh, M.S.; Abdollahzadeh, G. Socioeconomic Determinants of Sustainability of Agricultural Production in Rural Areas: A Case Study in Golestan Province. J. Sustain. Rural Dev. 2017, 1, 121-135. [CrossRef]

13. Bartoli, L.; De Rosa, M. Family farm business and access to rural development polices: A demographic perspective. Agric. Food Econ. 2013, 1, 12. [CrossRef]

14. Ren, C.; Liu, S.; Van Grinsven, H.; Reis, S.; Jin, S.; Liu, H.; Gu, B. The impact of farm size on agricultural sustainability. J. Clean. Prod. 2019, 220. [CrossRef]

15. Lebacq, T.; Baret, P.V.; Stilmant, D. Sustainability indicators for livestock farming. A review. Agron. Sustain. Dev. 2013, 33, 311-327. [CrossRef]

16. Hodbod, J.; Barreteau, O.; Allen, C.; Magda, D. Managing adaptively for multifunctionality in agricultural systems. J. Environ. Manag. 2016, 183, 379-388. [CrossRef] [PubMed]

17. Latruffe, L.; Diazabakana, A.; Bockstaller, C.; Desjeux, Y.; Finn, J.; Kelly, E.; Ryan, M.; Uthes, S. Measurement of sustainability in agriculture: A review of indicators. Stud. Agric. Econ. 2016, 118, 123-130. [CrossRef]

18. Lampridi, M.G.; Sorensen, C.G.; Bochtis, D. Agricultural Sustainability: A Review of Concepts and Methods. Sustainability 2019, 11, 5120. [CrossRef]

19. Lu, Y.L.; Chadwick, D.; Norse, D.; Powlson, D.; Shi, W.M. Sustainable intensification of China's agriculture: The key role of nutrient management and climate change mitigation and adaptation. Agric. Ecosyst. Environ. 2015, 209, 1-4. [CrossRef]

20. Satola, L.; Wojewodzic, T.; Sroka, W. Barriers to exit encountered by small farms in light of the theory of new institutional economics. Agric. Econ. Czech 2018, 64, 277-290.

21. Stepien, S.; Czyzewski, B.; Sapa, A.; Borychowski, M.; Poczta, W.; Poczta-Wajda, A. Eco-efficiency of small-scale farming in Poland and its institutional drivers. J. Clean. Prod. 2021, 279, 123721. [CrossRef]

22. Bell, L.W.; Moore, A.D.; Kirkegaard, J.A. Evolution in crop livestock integration systems that improve farm productivity and environmental performance in Australia. Eur. J. Agron. 2014, 57, 10-20. [CrossRef]

23. Blades, L.; Morgan, K.; Douglas, R.; Glover, S.; De Rosa, M.; Cromie, T.; Smyth, B. Circular biogas-based economy in a rural agricultural setting. Energy Procedia 2017, 123, 89-96. [CrossRef]

24. Wang, Z.; Liu, M.; Feng, Z.; Hua, L.; Xie, J.; Shao, G. A New Model of Recycling Agricultural Production. J. Agric. Sci. Technol. 2013, 14, 466-469, 537.

25. Weikard, H.P. Phosphorus recycling and food security in the long run: A conceptual modelling approach. Food Secur. 2016, 8 , 405-414. [CrossRef]

26. Almuktar, S.A.A.A.N.; Abed, S.N.; Scholz, M. Wetlands for wastewater treatment and subsequent recycling of treated effluent: A review. Environ. Sci. Pollut. Res. 2018, 25, 23595-23623. [CrossRef]

27. Xu, S.-W.; Li, G.-Q.; Li, Z.-M. China Agricultural Outlook for 2015-2024 Based on China Agricultural Monitoring and Earlywarning System. J. Integr. Agric. 2015, 14, 1889-1902. [CrossRef]

28. Bell, L.W.; Moore, A.D. Integrated crop-livestock systems in Australian agriculture: Trends, drivers and implications. Agric. Syst. 2012, 111, 1-12. [CrossRef]

29. Viola, I.; Marinelli, A. Life Cycle Assessment and Environmental Sustainability in the Food System. Agric. Agric. Sci. Procedia 2016, 8, 317-323. [CrossRef] 
30. Gaviglio, A.; Bertocchi, M.; Demartini, E. A Tool for the Sustainability Assessment of Farms: Selection, Adaptation and Use of Indicators for an Italian Case Study. Resources 2017, 6, 60. [CrossRef]

31. Arena, U.; Di Gregorio, F. A waste management planning based on substance flow analysis. Resour. Conserv. Recycl. 2014, 85, 54-66. [CrossRef]

32. Hu, M.; Zhang, C.; Dong, L.; Xiang, P.; Zhang, Q. Economical pillar of sustainability assessment on resource circulation. China Environ. Sci. 2018, 38, 4788-4800.

33. Sevigné-Itoiz, E.; Gasol, C.M.; Rieradevall, J. Methodology of supporting decision-making of waste management with material flow analysis (MFA) and consequential life cycle assessment (CLCA): Case study of waste paper recycling. J. Clean. Prod. 2015, 105, 253-262. [CrossRef]

34. Kasemset, C.; Chernsupornchai, J.; Pala-Ud, W. Application of MFCA in waste reduction: Case study on a small textile factory in Thailand. J. Clean. Prod. 2015, 108, 1342-1351. [CrossRef]

35. Huang, C.L.; Vause, J.; Ma, H.W.; Yu, C.P. Using material/substance flow analysis to support sustainable development assessment: A literature review and outlook. Resour. Conserv. Recycl. 2012, 68, 104-116. [CrossRef]

36. Susan, B.; Bernadette, O. Material flow accounting for an Irish rural community engaged in energy efficiency and renewable energy generation. J. Clean. Prod. 2016, 127, 363-373.

37. Wagner, B. A report on the origins of Material Flow Cost Accounting research activities. J. Clean. Prod. 2015, $108,1255-1261$. [CrossRef]

38. Zhou, Z.; Zhao, W.; Chen, X.; Zeng, H. MFCA extension from a circular economy perspective: Model modifications and case study. J. Clean. Prod. 2017, 149, 110-125. [CrossRef]

39. Christ, K.L.; Burritt, R.L. Material Flow Cost Accounting: A review and agenda for future research. J. Clean. Prod. 2015, 108, 1378-1389. [CrossRef]

40. Kokubu, K.; Kitada, H. Material Flow Cost Accounting and existing management perspectives. J. Clean. Prod. 2015, 108, 1279-1288. [CrossRef]

41. Christ, K.L.; Burritt, R.L. ISO 14051: A new era for MFCA implementation and research. Rev. Contab. 2016, 19, 1-9. [CrossRef]

42. Guenther, E.; Jasch, C.; Schmidt, M. Material Flow Cost Accounting-Looking back and ahead. J. Clean. Prod. 2015, 108, 1249-1254. [CrossRef]

43. Fakoya, M.B.; Poll, H.M.V.D. Integrating ERP and MFCA systems for improved waste-reduction decisions in brewery in South Africa. J. Clean. Prod. 2013, 40, 136-140. [CrossRef]

44. Sulong, F.; Sulaiman, M.; Norhayati, M.A. Material Flow Cost Accounting (MFCA) enablers and barriers: The case of a Malaysian small and medium-sized enterprise (SME). J. Clean. Prod. 2015, 108, 1365-1374. [CrossRef]

45. Nakajima, M.; Kimura, A.; Wagner, B. Introduction of material flow cost accounting (MFCA) to the supply chain: A questionnaire study on the challenges of constructing a low-carbon supply chain to promote resource efficiency. J. Clean. Prod. 2015, 108, 1302-1309. [CrossRef]

46. Prox, M. Material Flow Cost Accounting Extended to the Supply Chain -Challenges, Benefits and Links to Life Cycle Engineering. Procedia CIRP 2015, 29, 486-491. [CrossRef]

47. Gao, T.; Shen, L.; Shen, M. Analysis of material flow and consumption in cement production process. J. Clean. Prod. 2016, 112, 553-565. [CrossRef]

48. Song, T.; Yang, Z.; Chahine, T. Efficiency evaluation of material and energy flows, a case study of Chinese cities. J. Clean. Prod. 2016, 112, 3667-3675. [CrossRef]

49. Jean-Yves, C.; Julien, A.; Pierre-Yves, L. Down scaling material flow analysis: The case of the cereal supply chain in France. Ecol. Econ. 2015, 118, 67-80.

50. Haas, W.; Krausmann, F.; Wiedenhofer, D.; Heinz, M. How circular is the global economy? An assessment of material flows, waste production, and recycling in the European union and the world in 2005. J. Ind. Ecol. 2015, 0, 1-13. [CrossRef]

51. Xiong, F.; Xiao, X.; Chen, X.; Zhou, Z. The Path Optimization of Chinese Aluminum Corporation for Circular Economy Strategy Based on Resource Value Flow Model: A Case Study of CHINALCO. Environ. Eng. Manag. J. 2015, 14, $1923-1932$.

52. Wei, X.; Gu, Y. Comparative study on the value flow accounting of pig breeding in China. Econ. Geogr. 2018, 38, 152-160.

53. Asai, M.; Hayashi, T.; Yamamoto, M. Mental Model Analysis of Biogas Energy Perceptions and Policy Reveals Potential Constraints in a Japanese Farm Community. Sustainability 2019, 11, 225. [CrossRef]

54. Mwirigi, J.; Balana, B.B.; Mugisha, J.; Walekhwa, P.; Melamu, R.; Nakami, S.; Makenzi, P. Socio-economic hurdles to widespread adoption of small-scale biogas digesters in Sub-Saharan Africa: A review. Biomass Bioenergy 2014, 70, 17-25. [CrossRef]

55. Bin, M.R.; Qin, Y.Z.; Zhou, F.M. Environmental cost assessment of hog scale production in Hunan Province. Res. Agric. Mod. 2017, 38, 1044-1051.

56. Pang, J.; Chen, X.; Zhang, Z.; Li, H. Measuring Eco-efficiency of agriculture in China. Sustainability 2016, 8, 398. [CrossRef]

57. Sidhoum, A.A.; Serra, T.; Latruffe, L. Measuring sustainability efficiency at farm level: A data envelopment analysis approach. Eur. Rev. Agric. Econ. 2020, 47, 200-225. [CrossRef]

58. Grzelak, A.; Staniszewski, J.; Borychowski, M. Income or Assets—What Determines the Approach to the Environment among Farmers in A Region in Poland? Sustainability 2020, 12, 4917. [CrossRef] 